\title{
Evidence of icosahedral short-range order in Zr70Cu30 and Zr70Cu29Pd1 metallic glasses
}

SaksI, K.; Franz, H.; Jovari, P.; Klementlev, K.; Welter, E.; Ehnes, A.; Saida, J.; Inoue, A.; Jiang, Jianzhong

\section{Published in:}

Applied Physics Letters

Link to article, DOI:

$10.1063 / 1.1626266$

Publication date:

2003

Document Version

Publisher's PDF, also known as Version of record

Link back to DTU Orbit

Citation (APA):

Saksl, K., Franz, H., Jovari, P., Klementlev, K., Welter, E., Ehnes, A., Saida, J., Inoue, A., \& Jiang, J. (2003). Evidence of icosahedral short-range order in Zr70Cu30 and Zr70Cu29Pd1 metallic glasses. Applied Physics Letters, 83(19), 3924-3926. https://doi.org/10.1063/1.1626266

\section{General rights}

Copyright and moral rights for the publications made accessible in the public portal are retained by the authors and/or other copyright owners and it is a condition of accessing publications that users recognise and abide by the legal requirements associated with these rights.

- Users may download and print one copy of any publication from the public portal for the purpose of private study or research.

- You may not further distribute the material or use it for any profit-making activity or commercial gain

- You may freely distribute the URL identifying the publication in the public portal 


\title{
Evidence of icosahedral short-range order in $\mathrm{Zr}_{70} \mathrm{Cu}_{30}$ and $\mathrm{Zr}_{70} \mathrm{Cu}_{29} \mathrm{Pd}_{1}$ metallic glasses
}

\author{
K. Saksl, H. Franz, P. Jóvári, K. Klementiev, E. Welter, and A. Ehnes \\ HASYLAB at DESY, Notkestrasse 85, 22607 Hamburg, Germany \\ J. Saida \\ Center for Interdisciplinary Research, Tohoku University, Sendai 980-8578, Japan
}

A. Inoue

Institute for Materials Research, Tohoku University, Sendai 980-8577, Japan

J. Z. Jiang ${ }^{\text {a) }}$

Department of Materials Science and Engineering, Zhejiang University, Hangzhou, 310027,

People's Republic of China and Department of Physics, Building 307, Technical University of Denmark, DK-2800 Lyngby, Denmark

(Received 23 June 2003; accepted 18 September 2003)

\begin{abstract}
Change in local atomic environment during crystallization of Zr-based glassy alloys was studied by extended x-ray absorption fine structure (EXAFS) spectroscopy. The formation of icosahedral quasicrystalline phase followed by crystallization of tetragonal $\mathrm{CuZr}_{2}$ has been observed in the $\mathrm{Zr}_{70} \mathrm{Cu}_{29} \mathrm{Pd}_{1}$ glassy alloy during annealing up to $850 \mathrm{~K}$. On the other hand, the binary $\mathrm{Zr}_{70} \mathrm{Cu}_{30}$ alloy shows a single glassy to crystalline $\mathrm{CuZr}_{2}$ phase transformation. The local atomic environment of as-quenched $\mathrm{Zr}_{70} \mathrm{Cu}_{30}$ alloy is matched to an icosahedral local atomic configuration, which is similar to that of the as-quenched $\mathrm{Zr}_{70} \mathrm{Cu}_{29} \mathrm{Pd}_{1}$ alloy and the alloy annealed at $593 \mathrm{~K}$ containing icosahedral phase. Considering that the supercooled liquid region appears prior to crystallization in the $\mathrm{Zr}_{70} \mathrm{Cu}_{30}$ glassy alloy, the observed results support the theory claiming a strong correlation between the existence of local icosahedral short-range order and stability of the supercooled liquid state. (c) 2003 American Institute of Physics. [DOI: 10.1063/1.1626266]
\end{abstract}

Recently, after the discovery of the formation of icosahedral quasicrystals (I-phase) from $\mathrm{Zr}-\mathrm{Al}-\mathrm{Cu}-\mathrm{Ni}$ metallic glasses with high oxygen content, ${ }^{1}$ quasicrystals have been found to form upon crystallization in many $\mathrm{Zr}$-based alloy systems, such as $\mathrm{Zr}-(\mathrm{Pd}$ or $\mathrm{Pt}),{ }^{2-4} \mathrm{Zr}-\mathrm{Ni}-\left(\mathrm{Pd}, \mathrm{Au}, \mathrm{Pt}\right.$ or Ti) ${ }^{5,6}$ $\mathrm{Zr}-\mathrm{Cu}-\mathrm{Al}-\mathrm{O},{ }^{7} \mathrm{Zr}-\mathrm{Pd}-(\mathrm{Cu}, \mathrm{Fe}$ or $\mathrm{Co}),{ }^{8,9} \mathrm{Zr}-\mathrm{Cu}-\mathrm{Pd}-\left(\mathrm{Al}\right.$ or Ni), ${ }^{8}$ $\mathrm{Zr}-\mathrm{Al}-\mathrm{Ni}-\mathrm{Cu}-\mathrm{O},{ }^{1,10} \quad \mathrm{Zr}-\mathrm{Al}-\mathrm{Ni}-(\mathrm{Pd}, \quad \mathrm{Au}, \quad$ or $\mathrm{Pt}){ }^{11}$ $\mathrm{Zr}-\mathrm{Cu}-\mathrm{Ti}-\mathrm{Ni},{ }^{12} \mathrm{Zr}-\mathrm{Al}-\mathrm{Ni}-\mathrm{Cu}-(\mathrm{Ti}, \mathrm{Au}, \mathrm{Pt}, \mathrm{Pd}$ or $\mathrm{Ag}),{ }^{13-18}$ $\mathrm{Zr}-\mathrm{Ti}-\mathrm{Cu}-\mathrm{Ni}-\mathrm{Be},{ }^{19}$ and $\mathrm{Zr}-\mathrm{Ti}-\mathrm{Nb}-\mathrm{Cu}-\mathrm{Ni}-\mathrm{Al} .{ }^{20}$ Very recently, the formation of I-phase was reported in the binary $\mathrm{Zr}_{70} \mathrm{Cu}_{30}$ glassy alloy after addition of 1 at. \% Pd, Au or Pt. ${ }^{21}$ Because the nanometer-sized I-phase is formed as a primary metastable phase by substituting only 1 at. $\% \mathrm{Cu}$ with $\mathrm{Pd}$ in $\mathrm{Zr}_{70} \mathrm{Cu}_{30}$, Saida et al. suggested that icosahedral shortand/or medium-range order could already exist in the $\mathrm{Zr}_{70} \mathrm{Cu}_{30}$ glassy alloy. ${ }^{22}$ In this letter, we report evidence of the existence of icosahedral short-range order by examining the local environments of the $\mathrm{Zr}_{70} \mathrm{Cu}_{30}$ and $\mathrm{Zr}_{70} \mathrm{Cu}_{29} \mathrm{Pd}_{1}$ glassy alloys in the as-quenched and annealed states using the extended $\mathrm{x}$-ray absorption fine structure (EXAFS) technique.

Melt-spun $\mathrm{Zr}_{70} \mathrm{Cu}_{30}$ binary and $\mathrm{Zr}_{70} \mathrm{Cu}_{29} \mathrm{Pd}_{1}$ ternary alloys with a cross section of $0.03 \times 1 \mathrm{~mm}^{2}$ were produced from ingots prepared by arc melting high-purity metals (99.9\% Zr, 99.999\% Cu, 99.9\% Pd). The ternary alloy has been prepared by substituting Pd for 1 at. \% $\mathrm{Cu}$. Amorphous ribbons were obtained from these alloys by single-roller

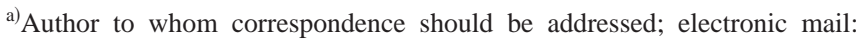
jiang@fysik.dtu.dk
}

melt spinning at a wheel surface velocity of $40 \mathrm{~m} / \mathrm{s}$ in purified $\mathrm{Ar}$ atmosphere. The oxygen content of the as-quenched ribbon samples was analyzed to be less then 800 mass ppm by inductively coupled plasma spectroscopy. The influence of oxygen on the transformation behavior can thus be disregarded. ${ }^{7}$

In situ $\mathrm{x}$-ray powder diffraction (XRD) measurements were performed at HASYLAB (Hamburg, Germany) on the experimental station Petra1 using monochromatic synchrotron radiation of $21 \mathrm{keV}$ and a two-dimensional detector. The sample was continuously heated for in situ measurements from 300 to $850 \mathrm{~K}$ at a rate of $10 \mathrm{~K} / \mathrm{min}$ under vacuum. EXAFS measurements were performed at the A1 station in transmission geometry. The same heater as in XRD measurement was used for pre-annealing of samples directly on the beamline. Data were taken after cooling down to $300 \mathrm{~K}$ with the aim of reducing the temperature-dependent damping of the oscillatory part of the absorption coefficient. Measured spectra were analyzed by standard procedures of data reduction, using the program VIPER. ${ }^{23}$ The Fourier transformation (FT) gives a radial distribution function (RDF), modified by the phase shifts due to the absorbing and backscattering atoms. A selected number of shells were backtransformed into k-space. The structural parameters $N$ (coordination number), $R$ (interatomic distance), and $\sigma$ (relative displacement of atoms) were obtained from least squares fitting in k-space, using theoretical phases and amplitude functions calculated by the FEFF- 8 code. ${ }^{24}$

Figures 1(a) and 1(b) show XRD patterns of $\mathrm{Zr}_{70} \mathrm{Cu}_{30}$ and $\mathrm{Zr}_{70} \mathrm{Cu}_{29} \mathrm{Pd}_{1}$ at different stages of annealing. Up to 583 $\mathrm{K}$, the patterns of both samples exhibit a broad peak located 


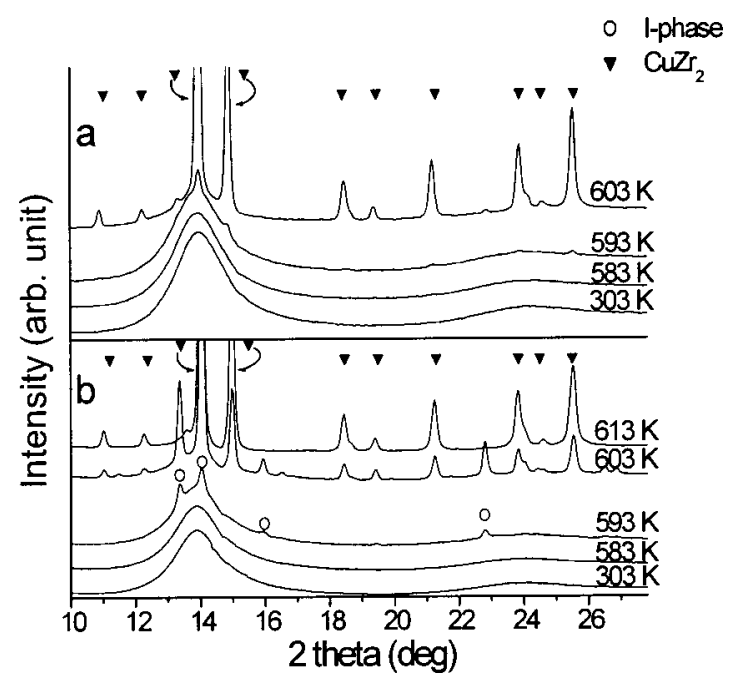

FIG. 1. In situ high-temperature $\mathrm{XRD}$ patterns of (a) $\mathrm{Zr}_{70} \mathrm{Cu}_{30}$ and (b) $\mathrm{Zr}_{70} \mathrm{Cu}_{29} \mathrm{Pd}_{1}$ ribbon samples using a wavelength of $0.05904 \mathrm{~nm}$.

at $2 \theta \approx 13.8^{\circ}$ characteristic for the amorphous structure. At $593 \mathrm{~K}$, XRD patterns of $\mathrm{Zr}_{70} \mathrm{Cu}_{30}$ and $\mathrm{Zr}_{70} \mathrm{Cu}_{29} \mathrm{Pd}_{1}$ samples show diffraction peaks which can be indexed as a tetragonal $\mathrm{CuZr}_{2}$ phase $(a=0.322 \mathrm{~nm}$ and $c=1.118 \mathrm{~nm}$, space group $I 4 / \mathrm{mmm}$ ) and an icosahedral quasicrystalline phase (Iphase), respectively. At $603 \mathrm{~K}$, both I-phase and $\mathrm{CuZr}_{2}$ phase are observed in $\mathrm{Zr}_{70} \mathrm{Cu}_{29} \mathrm{Pd}_{1}$ sample, while a tiny trace of the I-phase $\left(2 \theta \approx 13.2^{\circ}, 16^{\circ}\right.$, and $\left.22.8^{\circ}\right)$ was also present in $\mathrm{Zr}_{70} \mathrm{Cu}_{30}$ sample. Above $613 \mathrm{~K}$, only the $\mathrm{CuZr}_{2}$ phase is detected in both samples. Figure 2 shows schematic drawings of an icosahedral cluster around a $\mathrm{Zr}$ atom and the $\mathrm{CuZr}_{2}$ lattice, respectively.

Figure 3(a) shows the normalized experimental EXAFS spectra measured at the $\mathrm{Zr} \mathrm{K}$ edge of $\mathrm{Zr}_{70} \mathrm{Cu}_{29} \mathrm{Pd}_{1}$ in the as-prepared state and after pre-annealing at 593 and $773 \mathrm{~K}$. Corresponding FTs are shown in Fig. 3(b). Measured EXAFS signals as well as FTs of the sample annealed at $593 \mathrm{~K}$ (where the I-phase was detected by XRD) and as-prepared sample look very similar. This indicates similar local atomic environment around $\mathrm{Zr}$ in both stages. Overlapping of two shells in RDF [marked by arrows on Fig. 3(d)] and only one smooth peak in the RDF around $\mathrm{Cu}$ atoms (EXAFS signal

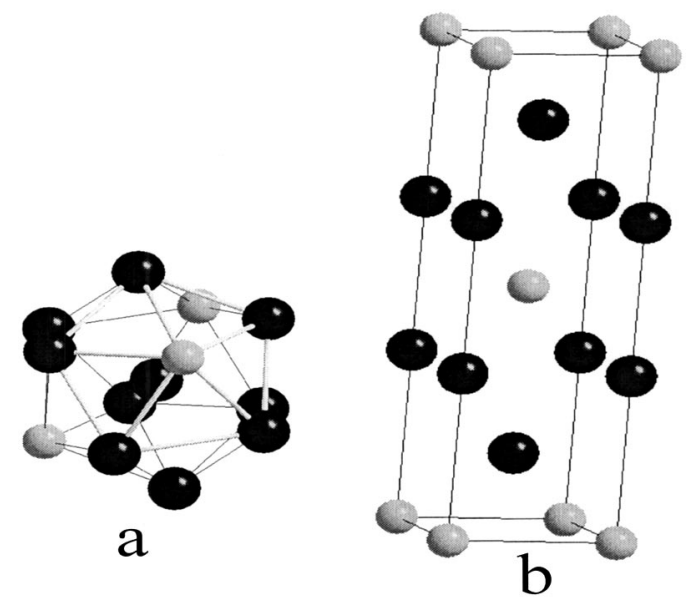

FIG. 2. Schematic drawings of (a) icosahedral cluster and (b) unit cell of tetragonal $\mathrm{CuZr}_{2}$ structure with black spheres for $\mathrm{Zr}$ atoms and white spheres for $\mathrm{Cu}$ atoms.

Downloaded 01 Apr 2010 to 192.38.67.112. Redistribution subject to $\overline{\overline{\text { AlP license or copyright; see http://apl.aip.org/apl/copyright.jsp }}}$

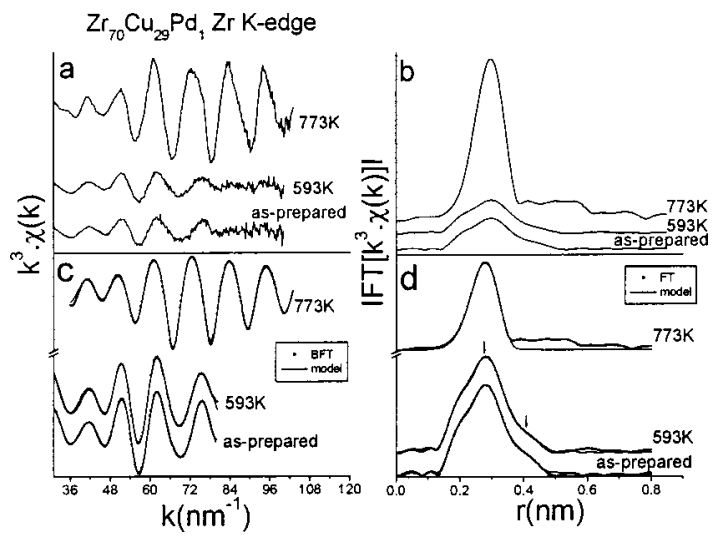

FIG. 3. (a) Experimental $\mathrm{k}^{3} \cdot \chi(\mathrm{k})$ for $\mathrm{Zr}_{70} \mathrm{Cu}_{29} \mathrm{Pd}_{1}$ alloy in as-prepared stage and after pre-annealing at 593 and $773 \mathrm{~K}$ measured above $\mathrm{Zr}$ edge, (b) Fourier transforms of (a), (c) Fourier filtered signal (dots) from selected number of shells and simulated EXAFS spectra (line), and (d) Fourier transforms of (c).

measured above $\mathrm{Cu}$ edge not shown here) indicate the existence of short-range order around $\mathrm{Zr}$. Saida et $_{\mathrm{al}}{ }^{22}$ reported a coordination number $\mathrm{N} \approx 12$ around $\mathrm{Zr}$ in glassy $\mathrm{Zr}_{70} \mathrm{Cu}_{30}$, suggesting the formation of icosahedral configurations around Zr. For calculations a model of icosahedral clusters around the $\mathrm{Zr}$ atoms was chosen (Fig. 2). The outer shells of the icosahedral cluster model are composed of $\mathrm{Zr}$ and $\mathrm{Cu}$. Despite the fact that 1 at. \% of Pd plays an important role in stabilizing the local atomic order Pd was excluded from the model calculations. By using the theoretically calculated amplitude and phase factors spectra taken from as-prepared and pre-annealed (593 K) $\mathrm{Zr}_{70} \mathrm{Cu}_{29} \mathrm{Pd}_{1}$ can be fitted. The outline of our fitting procedure is as follows. Two shells in the range of 0.12 to $0.48 \mathrm{~nm}$ were back transformed to $\mathrm{k}$-space. Each shell consists of two subshells $\mathrm{Zr}-\mathrm{Zr}$ and $\mathrm{Zr}-\mathrm{Cu}$. The total coordination number in each shell was constrained $N_{\mathrm{Zr}-\mathrm{Zr}}$ $+N_{\mathrm{Zr}-\mathrm{Cu}}=12$. The structural parameters, $R_{i}, \sigma_{i}$ and relative coordination number from each subshell, were obtained by fitting of back Fourier filtered signal. Figures 3(c) and 3(d) show results obtained from the best fitting, refined structural parameters from the fits are listed in Table I. To analyze the EXAFS signal of $\mathrm{Zr}_{70} \mathrm{Cu}_{29} \mathrm{Pd}_{1}$ annealed at $773 \mathrm{~K}$ (where only $\mathrm{CuZr}_{2}$ diffraction peaks were present in XRD), another approach was used. The $\mathrm{Zr}$ atom in the tetragonal $\mathrm{CuZr}_{2}$ phase is surrounded by four $\mathrm{Cu}$ atoms at a distance of 0.288 $\mathrm{nm}$, four $\mathrm{Zr}$ atoms at a distance of $0.307 \mathrm{~nm}$ and four $\mathrm{Zr}$

TABLE I. Structural parameters for $\mathrm{Zr}_{70} \mathrm{Cu}_{29} \mathrm{Pd}_{1}$ and $\mathrm{Zr}_{70} \mathrm{Cu}_{30}$ samples by using an icosahedral model.

\begin{tabular}{|c|c|c|c|c|c|c|c|}
\hline \multicolumn{8}{|c|}{$\mathrm{Zr}_{70} \mathrm{Cu}_{29} \mathrm{Pd}_{1} \mathrm{Zr}$ edge } \\
\hline \multirow{2}{*}{$\begin{array}{l}\text { Annealing } \\
\text { temperature } \\
{[\mathrm{K}]}\end{array}$} & \multirow{2}{*}{$\begin{array}{l}\text { Number } \\
\text { of the } \\
\text { shell }\end{array}$} & \multicolumn{2}{|c|}{$R[\mathrm{~nm}] \pm 0.0001$} & \multicolumn{2}{|c|}{$N \pm 0.1$} & \multicolumn{2}{|c|}{$\sigma[\mathrm{nm}] \pm 0.0001$} \\
\hline & & $\mathrm{Zr}-\mathrm{Zr}$ & $\mathrm{Zr}-\mathrm{Cu}$ & $\mathrm{Zr}-\mathrm{Zr}$ & $\mathrm{Zr}-\mathrm{Cu}$ & $\mathrm{Zr}-\mathrm{Zr}$ & $\mathrm{Zr}-\mathrm{Cu}$ \\
\hline \multirow[t]{2}{*}{300} & 1 & 0.2761 & 0.2798 & 9.2 & 2.8 & 0.0235 & 0.0145 \\
\hline & 2 & 0.4483 & 0.4514 & 7.7 & 4.3 & 0.0230 & 0.0182 \\
\hline \multirow[t]{2}{*}{593} & 1 & 0.2759 & 0.2795 & 8.9 & 3.1 & 0.0226 & 0.0158 \\
\hline & 2 & 0.4479 & 0.4520 & 7.8 & 4.2 & 0.0221 & 0.0176 \\
\hline \multicolumn{8}{|c|}{$\mathrm{Zr}_{70} \mathrm{Cu}_{30} \mathrm{Zr}$ edge } \\
\hline \multirow[t]{2}{*}{300} & 1 & 0.2763 & 0.2794 & 9.1 & 2.9 & 0.0241 & 0.0138 \\
\hline & 2 & 0.4479 & 0.4517 & 7.9 & 4.1 & 0.0226 & 0.0212 \\
\hline
\end{tabular}


TABLE II. Structural parameters for $\mathrm{Zr}_{70} \mathrm{Cu}_{29} \mathrm{Pd}_{1}$ and $\mathrm{Zr}_{70} \mathrm{Cu}_{30}$ samples by using a $\mathrm{CuZr}_{2}$ model.

\begin{tabular}{|c|c|c|c|c|c|c|c|c|c|}
\hline \multicolumn{10}{|c|}{$\mathrm{Zr}_{70} \mathrm{Cu}_{29} \mathrm{Pd}_{1} \mathrm{Zr}$ edge } \\
\hline \multirow{2}{*}{$\begin{array}{l}\text { Annealing } \\
\text { temperature } \\
{[\mathrm{K}]}\end{array}$} & \multicolumn{3}{|c|}{$R[\mathrm{~nm}] \pm 0.0001$} & \multicolumn{3}{|c|}{$N$} & \multicolumn{3}{|c|}{$\sigma[\mathrm{nm}] \pm 0.0001$} \\
\hline & $\mathrm{Zr}-\mathrm{Cu}$ & $\mathrm{Zr}-\mathrm{Zr}$ & $\mathrm{Zr}-\mathrm{Zr}$ & $\mathrm{Zr}-\mathrm{Cu}$ & $\mathrm{Zr}-\mathrm{Zr}$ & $\mathrm{Zr}-\mathrm{Zr}$ & $\mathrm{Zr}-\mathrm{Cu}$ & $\mathrm{Zr}-\mathrm{Zr}$ & $\mathrm{Zr}-\mathrm{Zr}$ \\
\hline 773 & 0.2807 & 0.3062 & 0.3190 & 4 & 4 & 4 & 0.0172 & 0.0113 & 0.0103 \\
\hline \multicolumn{10}{|c|}{$\mathrm{Zr}_{70} \mathrm{Cu}_{30} \mathrm{Zr}$ edge } \\
\hline 593 & 0.2787 & 0.3074 & 0.3187 & 4 & 4 & 4 & 0.0184 & 0.0128 & 0.0148 \\
\hline 773 & 0.2807 & 0.3067 & 0.3216 & 4 & 4 & 4 & 0.0171 & 0.0106 & 0.0103 \\
\hline
\end{tabular}

atoms at a distance of $0.322 \mathrm{~nm}$. From the $\mathrm{CuZr}_{2}$ model new amplitudes and phase factors were calculated. The major peak in the RDF from 0.1 to $0.38 \mathrm{~nm}$ was back transformed to k-space, and the resulting filtered signal was fitted by using coordination number constrains for each subshell. Figures 3(c) and 3(d) show the fit and the structural parameters are listed in Table II. Figure 4(a) shows normalized EXAFS spectra measured at the $\mathrm{Zr} \mathrm{K}$ edge taken from as-prepared $\mathrm{Zr}_{70} \mathrm{Cu}_{30}$ and the same sample pre-annealed at 593 and 773 $\mathrm{K}$. The oscillatory signal of as-prepared $\mathrm{Zr}_{70} \mathrm{Cu}_{30}$ alloy is similar to that of as-prepared $\mathrm{Zr}_{70} \mathrm{Cu}_{29} \mathrm{Pd}_{1}$ alloy, however, the signal from $\mathrm{Zr}_{70} \mathrm{Cu}_{30}$ alloy annealed at $593 \mathrm{~K}$ is significantly different (pronounced oscillations of $\mathrm{k}^{3} \cdot \chi(k)$ up to 100 $\mathrm{nm}^{-1}$ and almost double amplitude) compared to that of the as-prepared state as well as the signal from $\mathrm{Zr}_{70} \mathrm{Cu}_{29} \mathrm{Pd}_{1}$ annealed at the same temperature. Corresponding differences can also be seen after FT of the oscillatory signals to r-space [Fig. 4(b)]. EXAFS spectra of as-prepared $\mathrm{Zr}_{70} \mathrm{Cu}_{30}$ were analyzed by the same fitting procedure used for the quasicrystalline $\mathrm{Zr}_{70} \mathrm{Cu}_{29} \mathrm{Pd}_{1}$ sample. Spectra from pre-annealed samples were fitted using the procedure for the $\mathrm{CuZr}_{2}$ structure. The best fits are shown on Figs. 4(c) and 4(d), and resulting parameters from the fits are listed in Tables I and II. From these examinations, we can summarize that the local atomic environments of the as-quenched $\mathrm{Zr}_{70} \mathrm{Cu}_{30}$ glassy alloy are similar to those in the as-quenched and annealed at $593 \mathrm{~K}$ (I-phase is formed) in the $\mathrm{Zr}_{70} \mathrm{Cu}_{29} \mathrm{Pd}_{1}$ glassy alloy, where the corresponding local atomic environments match to the icosahedral local atomic configuration.

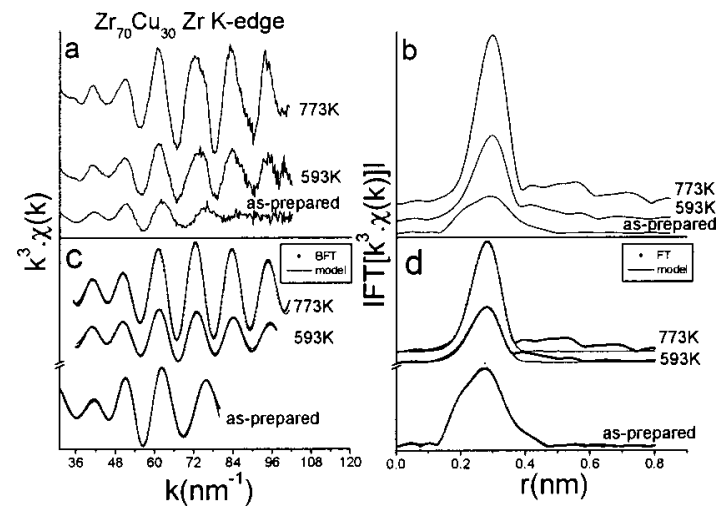

FIG. 4. (a) Experimental $k^{3} \cdot \chi(k)$ for $\mathrm{Zr}_{70} \mathrm{Cu}_{30}$ alloy in as-prepared stage and after pre-annealing at 593 and $773 \mathrm{~K}$ measured above $\mathrm{Zr}$ edge, (b) Fourier transforms of (a), (c) Fourier filtered signal (dots) from selected number of shells and simulated EXAFS spectra (line), and (d) Fourier transforms of (c).

Downloaded 01 Apr 2010 to 192.38.67.112. Redistribution subject to AIP license or copyright; see http://apl.aip.org/apl/copyright.jsp
These local atomic environments change into the $\mathrm{CuZr}_{2}$ structure with annealing at the temperature over $593 \mathrm{~K}$ in the $\mathrm{Zr}_{70} \mathrm{Cu}_{30}$ and at $773 \mathrm{~K}$ in the $\mathrm{Zr}_{70} \mathrm{Cu}_{29} \mathrm{Pd}_{1}$ glassy alloys, indicating that the local atomic arrangement in the binary composition is more flexible (can more easily adopt stable $\mathrm{CuZr}_{2}$ structure) than the alloy containing Pd. By addition of Pd the local icosahedral atomic configuration becomes more rigid, suppressing the redistribution of constituent elements to form the $\mathrm{CuZr}_{2}$ phase. Since the supercooled liquid state appears prior to crystallization in these alloys, it is concluded that the formation of icosahedral local structure is supposed to be a dominant factor for the high glass-forming ability; that is, high stability of the supercooled liquid state of the Zr-based glassy alloys.

${ }^{1}$ U. Köster, J. Meinhardt, S. Roos, and H. Liebertz, Appl. Phys. Lett. 69, 179 (1996).

${ }^{2}$ J. Saida, M. Matsushita, and A. Inoue, Appl. Phys. Lett. 77, 73 (2000).

${ }^{3}$ B. S. Murty, D. H. Ping, and K. Hono, Appl. Phys. Lett. 77, 1102 (2000).

${ }^{4}$ J. Z. Jiang, K. Saksl, J. Saida, A. Inoue, H. Franz, K. Messel, and C. Lathe, Appl. Phys. Lett. 80, 781 (2002).

${ }^{5}$ J. Saida, M. Matsushita, C. Li, and A. Inoue, Appl. Phys. Lett. 76, 3558 (2000).

${ }^{6}$ S. Yi and D. H. Kim, J. Mater. Res. 15, 892 (2000).

${ }^{7}$ B. S. Murty, D. H. Ping, K. Hono, and A. Inoue, Appl. Phys. Lett. 76, 55 (2000)

${ }^{8}$ B. S. Murty, D. H. Ping, K. Hono, and A. Inoue, Scr. Mater. 43, 103 (2000).

${ }^{9}$ M. Matsushita, J. Saida, C. Li, and A. Inoue, J. Mater. Res. 15, 1280 (2000).

${ }^{10}$ J. Eckert, N. Mattern, M. Zinkevitch, and M. Seidel, Mater. Trans., JIM 39, 623 (1998).

${ }^{11}$ A. Inoue, J. Saida, M. Matsushita, and T. Sakurai, Mater. Trans., JIM 41, $362(2000)$.

${ }^{12}$ D. V. Louzguine and A. Inoue, Appl. Phys. Lett. 78, 1841 (2001).

${ }^{13}$ L. Q. Xing, J. Eckert, W. Löser, and L. Schultz, Appl. Phys. Lett. 74, 664 (1999).

${ }^{14}$ M. W. Chen, T. Zhang, A. Inoue, A. Sakai, and T. Sakural, Appl. Phys. Lett. 75, 1697 (1999).

${ }^{15}$ A. Inoue, T. Zhang, J. Saida, M. Matsushita, M. W. Chen, and T. Sakurai, Mater. Trans., JIM 40, 1181 (1999).

${ }^{16}$ J. K. Lee, G. Choi, D. H. Kim, and W. T. Kim, Appl. Phys. Lett. 77, 978 (2000).

${ }^{17}$ J. Z. Jiang, A. R. Rasmussen, C. H. Jensen, Y. Lin, and P. L. Hansen, Appl. Phys. Lett. 80, 2090 (2002).

${ }^{18}$ J. Z. Jiang, Y. X. Zhuang, H. Rasmussen, J. Saida, and A. Inoue, Phys. Rev. B 64, 094208 (2001).

${ }^{19}$ N. Wanderka, M. P. Macht, M. Seidel, S. Mechler, K. Ståhl, and J. Z. Jiang, Appl. Phys. Lett. 77, 3935 (2000).

${ }^{20}$ U. Kuhn, J. Eckert, N. Mattern, and L. Schultz, Appl. Phys. Lett. 77, 3176 (2000).

${ }^{21}$ J. Saida, N. Matsushita, and A. Inoue, Mater. Trans., JIM 43, 1937 (2002).

${ }^{22}$ J. Saida, M. Kasai, E. Matsubara, and A. Inoue, Ann. Chim. Sci. Matér. 27, 77 (2002).

${ }^{23}$ K. V. Klementev, J. Phys. D 34, 209 (2001).

${ }^{24}$ A. L. Ankudinov, B. Ravel, J. J. Rehr, and S. D. Conradson, Phys. Rev. B 58, 7565 (1998) 